\title{
【奨励賞研究】
}

\section{心臓の拡張不全の理解に向けた カエル心臓の受動的伸展性の評価}

\author{
伊藤 愛 \\ 名古屋工業大学 工学部 創造工学教育課程
}

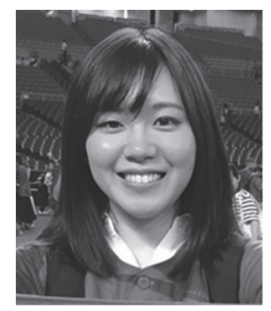

\section{1. 緒言}

近年, 高齢化に伴う拡張不全の症例が増加しており, 1)その対策 が望まれている. 拡張不全は, 心筋組織の硬化により心室の受動 的伸展性(伸びやすさ)が低下することによって生じる.心室の受動 的伸展性は, 心筋細胞の収縮ユニットであるサルコメアを構成する, コネクチン分子の影響が大きい2)ことから，拡張不全の直接原因とし てコネクチンが注目されている. しかしながら, 我々の心臟が拡張不 全を発症する根本原因については, ほとんどわかっていない．

そこで本研究では, 進化の観点から心臟の拡張不全への理解を 深めるために, 哺乳類より先行して出現した両生類のカエルの心室 の受動的伸展性を評価した. 先行研究 ${ }^{3)}$ で調べられているラット(哺 乳類)とカメ(爬虫類)の心室の受動的伸展性, 細胞の形態, サルコメ アと比較することで, 受動的伸展性の進化の方向性を探った.

\section{2. 方法}

\section{1 心室の受動的伸展性の評価 ${ }^{3)}$}

臟器レベルで心室の受動的伸展性の評価をするために, 心室内 の圧力-容積関係を計測可能な装置を作製した. 実験には, アフリ カツメガエルを用いた. まず, 大動脈に注射針(NN-2425R, テルモ) を挿入した後に心臟を単離し, 装置に取り付けた. 続いて, 心室に シリンジポンプ(ヒュージョンタッチ 200 ，ケニス)で心筇保護液を一定 スピードで持続的に注入し，このときの心室内圧の変化を圧力トラ ンスデューサとひずみアンプ(DPM-911B, 共和電業)で測定した. 実験終了後, 水分を除去して心室質量を計測した. 大きさの異なる 心室の受動的伸展性を比較するために, 心室容積を心室質量で 割った正規化心室容積を算出儿, 圧-正規化容積関係を求めた.

\section{2 単離心筋細胞の形態とサルコメアの長さの評価}

カメの心筋細胞の単離方法3)を参考にして, カエルの心筇細胞を 単離し, 倒立顕微鏡(IX73, オリンパス)と60 倍油浸対物レンズ (PLANPON60X，オリンパス)で観察した. 撮影画像から ImageJ 1.52s のプラグインである SarcOptiM)を用いてサルコメアの長さを測 定した.

\section{3. 結果および考察}

カエルの心室は加圧に伴い, 次第に膨らんだ(Fig.1). カエルの 心室の圧-正規化容積関係の典型例を先行研究 ${ }^{3) の カ メ と ラ ッ ト の ~}$

データと比較した(Fig.1). カエルの心室の受動的伸展性は, カメと 同程度であったのに対し,ラットよりも著しく高かった。

カエルの心筋細胞(Fig.2)は, カメと同様に紐状であった. ラットと 比較すると, 収縮方向(長軸方向) と直交する断面積は顕著に小さ かった. このような形状的特徴から, カエルやカメの心筋細胞は, 細 胞単体レベルにおいては, ラットよりも長軸方向の負荷に対して軟ら かく, 受動的伸展性が高いと考えられる.

カエルのサルコメアの長さは, ラットよりも有意に長く, カメと同程 度であった(Fig.3). サルコメアが長いほどコネクチンは長く, 3,5)コネク チンが長いほじコネクチンは軟らかい 3)と報告されている.したがっ て, 哺乳類のラットのコネクチンは, 爬虫類のカメや両生類のカエル よりも著しく短く, 硬いことが推測される。

以上より, 我々哺乳類の心臟は, 進化的に先行して出現した爬 虫類や両生類よりも臟器・細胞・分子レベルで硬い可能性が示唆さ れた. 春椎動物の心臟が伸展性を制限する方向に進化した結果, 加齢に伴う付加的な心臓の硬化に脆弱となり, 我々の心臟は拡張 不全を生じやすくなった可能性がある. 今後も春椎動物の拡張機 能を比較し, 我々の心臟が拡張不全を起こす根本原因を追求して いきたい。

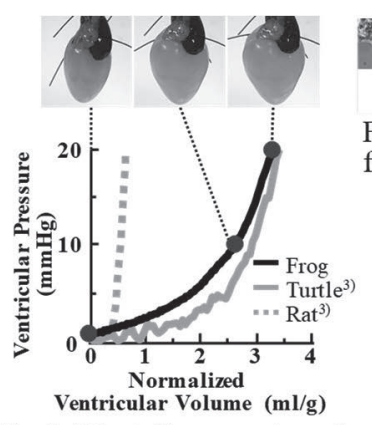

Fig. 1 Diastolic property and state of heart during pressurization. Fig. 3 Sarcomere Length.

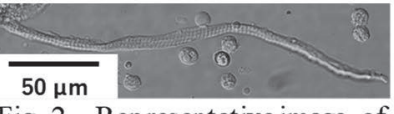

Fig. 2 Representative image of frog cardiomy ocy te.

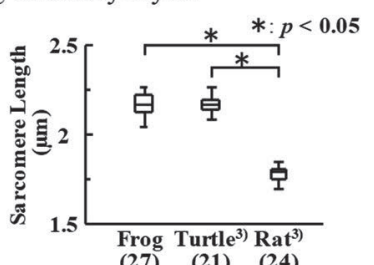

参考文献

1) Senni M, Tribouilloy CM, Rodeheffer RJ et al., Circulation, 98, 2282-2289, 1998

2) Granzier HL and Lrving TC, Biophys J, 68(3), 1027-1044, 1995

3) Honda T, Ujihara Y, Hanashima A, Hashimoto K, Tanemoto K, Mohri S, Kawasaki Med Journal, 44, 1-17, 2018

4) Pasqualin C, Gannier F, Yu A, Malécot CO, Bredeloux P, Maupoil V, Am J Physiol Cell Physiol, 311(2), C277-283, 2016

5) Hanashima A, Hashimoto K, Ujihara Y et al., Gene, 596(5), 19-26, 2017 